Annals of Warsaw University of Life Sciences - SGGW

Land Reclamation No 46 (3), 2014: 247-261

(Ann. Warsaw Univ. of Life Sci. - SGGW, Land Reclam. 46 (3), 2014)

\title{
Spatiotemporal variations of tropospheric ozone concentrations in the Warsaw Agglomeration (Poland)
}

\author{
KATARZYNA ROZBICKA ${ }^{1}$, TOMASZ ROZBICKI ${ }^{2}$ \\ ${ }^{1}$ Laboratory - Water Center, Warsaw University of Life Sciences - SGGW \\ ${ }^{2}$ Department of Hydraulic Engineering, Warsaw University of Life Sciences - SGGW
}

\begin{abstract}
Spatiotemporal variations of tropospheric ozone concentrations in the Warsaw Agglomeration (Poland). The study uses ozone concentrations from stations in Warsaw Agglomeration and its vicinity. Diversity of localizations of considered station, in terms of type of emissivity, allows on comparison of air pollution conditions by ozone in Warsaw area. Concentration of ozone in summer and spring were above twice greater than the concentration in autumn and winter. The greatest differences between weekend days concentration and work days concentration occur during autumn and winter, but in the same time the differences during the day are the least, especially in urban site stations. Statistics analysis shows strong relationship between ozone concentration and nitrogen dioxide concentration and meteorological elements especially for days with high level of ozone concentration. For these days regression equations were statistically significant $(\alpha=1 \%)$ and correlation coefficients were greater than 0.81 . Polynomial of IV power is the best fitted function of one-hourly values of ozone concentration course in particular seasons.
\end{abstract}

Key words: ozone, temporal variation, polynomials function, urban agglomeration

\section{INTRODUCTION}

Ozone in the troposphere can arise from a natural process of downward transport from the stratosphere, but in situ photochemical production resulting from anthropogenic precursor emissions dominates globally. Pollution ozone is formed in a mixture of reactive nitrogen oxides
$\left(\mathrm{NO}_{\mathrm{x}}\right)$ and volatile organic compounds (VOC) reacting in the presence of sunlight; $\mathrm{NO}_{\mathrm{x}}$ is usually the limiting ozone precursor. Reactions with $\mathrm{HO}_{\mathrm{x}}$, dry deposition and titration with NO remove ozone (Bloomer et al. 2010).

$\mathrm{NO}+\mathrm{O}_{3} \rightarrow \mathrm{NO}_{2}+\mathrm{O}_{2}$

The $\mathrm{NO}_{2}$ thus produced acts as a night-time reservoir and ozone is reformed in the morning as photolysis resume.

$\mathrm{NO}_{2}+h v \rightarrow \mathrm{NO}+\mathrm{O}$

$\mathrm{O}+\mathrm{O}_{2}(+\mathrm{M}) \rightarrow \mathrm{O}_{3}(+\mathrm{M})$

Recently, the reaction of nitrogen dioxide with ozone to produce the nitrate radical, and subsequent reactions with volatile organic compounds (VOC) to produce organic nitrogen compounds, such as alky nitrates, have been recognized as important reservoirs of $\mathrm{NO}_{\mathrm{x}}$ (Bloomer et al. 2010).

$$
\begin{aligned}
& \mathrm{NO}_{2}+\mathrm{O}_{3} \rightarrow \mathrm{NO}_{3}+\mathrm{O}_{2} \\
& \mathrm{NO}_{3}+\mathrm{VOC} \rightarrow \mathrm{R}-\mathrm{ONO}_{2}
\end{aligned}
$$

Thus, at a given VOC level, the $\mathrm{NO}_{\mathrm{x}}$, mixing ratio produces a maximum amount of ozone (Fujita et al. 2003a, b).

These atmospheric chemical mechanisms for ozone formation can be observed in an urban weekly cycle in which 
changes in precursor concentrations occur between weekdays and weekends. Slightly lower or higher urban ozone concentrations have been reported in some cities of North America, Europe and Asia during weekends (Seguel et al. 2012, e.g. Atkinson-Palombo et al. 2006; Blanchard et al. 2008; Geng et al. 2008; Shan et al. 2008) despite the substantial reduction of $\mathrm{NO}_{\mathrm{x}}$ emissions due to lower emissions from traffic and industrial sources. This phenomenon is known as the WE - weekend effect (Seguel et al. 2012, e.g. Dodge 1977). An appropriate understanding of WE conditions may provide effective strategies for atmospheric urban pollution control (Seguel et al. 2012, e.g. Duan et al. 2008).

Although other hypotheses have been proposed, such as pollutant carryover near the ground or loft, higher weekend VOC emissions, or greater photolysis due to decreased emissions of fine particles, the $\mathrm{NO}_{\mathrm{x}}$ reduction hypothesis is the most consistent explanation (Seguel et al. 2012, e.g. Fujita et al. 2003a, b). Given reaction (1) a decrease in $\mathrm{NO}$ emissions results in less $\mathrm{O}_{3}$ titration, which results in higher morning $\mathrm{O}_{3}$ on weekends. By contrast, less $\mathrm{NO}_{2}$ results in more $\mathrm{OH}$ to initiate $\mathrm{O}_{3}$ production because inhibition of termination reaction (6) favors faster $\mathrm{O}_{3}$ accumulation on weekends (Seguel et al. 2012).

$$
\mathrm{OH}+\mathrm{HO}_{2} \rightarrow \mathrm{H}_{2} \mathrm{O}+\mathrm{O}_{2}
$$

Other researchers have also concluded that the primary cause for higher ozone on weekends is the reduction in $\mathrm{NO}_{\mathrm{x}}$ emissions in a VOC-limited chemical regime (Marr and Harley 2002; Heuss et al. 2003; Lawson 2003; Blanchard and Tanenbaum 2006).
In this work, statistical characteristics of ground level ozone are analyzed according to the field monitoring data in four stations - three urban and one rural areas. The study deals with the characteristics of seasonal, monthly and daily mean ozone level under different climatic conditions at all stations. Reasons for the observed spatial and temporal variations of ozone levels are discussed.

\section{MATERIAL AND METHODS}

The study uses ozone and nitrogen dioxide imission and meteorological data (air temperature, relative humidity, direction and velocity of wind, solar radiation intensity and barometric pressure) from the Warsaw Agglomeration managed by the Regional Inspectorate for Environmental Protection's air quality monitoring stations. The stations represent different types of Warsaw areas and its vicinity. They are Ursynów (MzWarszUrsynow), Krucza (MzWarszKrucza), Legionowo (MzLegionZegIMGW) and Granica (MzGranicaKPN) - locations of the stations are presented in Figure 1. The station Ursynow is situated south of the city centre, close to the University campus but in surrounding of tall buildings of settlement and this station represents the peripheral districts of Warsaw. The station Krucza is located in the city centre (at a distance of about $80 \mathrm{~m}$ ) close to the very high traffic streets Al. Jerozolimskie, Marszałkowska (a traffic intensity of approx. 20,000 vehicles daily) (Majewski and Ćwiek 2013) and represents the city centre's pollution background. Around the station occurs dense multifamily residential development. The 
station in Legionowo, which represents suburb pollution background. is located north of the centre of Warsaw, outside its administrative borders. The station Granica is located in the Kampinos National Park, the largest forest complex in the vicinity of Warsaw, about $30 \mathrm{~km}$ to the West and represents regional air pollution background. Diversity of localizations of considered stations, in terms of type of emissivity, allows on comparison of air pollution conditions by troposphere ozone in Warsaw Agglomeration and its vicinity

Hourly values of ozone concentration were analyzed for the period from 1 January 2008 to 31 December 2012. Characteristic of air pollution of ozone was elaborated by the use of calculated average values of annual, monthly, seasonal and hourly concentration. value were calculated and number of days with excess of limit value in analyzed period. In addition average values of ozone concentration for seasons (spring, summer, autumn and winter) with partition on work days (Monday to Friday) and weekend days (Saturday and Sunday) were calculated.

Diurnal average course of troposphere ozone concentration was presented on the base average hourly values calculated for four seasons and for work days (Monday to Friday) and weekend days. It was conducted polynomial analyses by pollutant and location to identify hourly cycles in pollution metrics of ozone. This courses was describes by the polynomial function. In statistical analysis polynomial of IV power is the best function describing the charts of diurnal average courses of tropospheric ozone concentration:

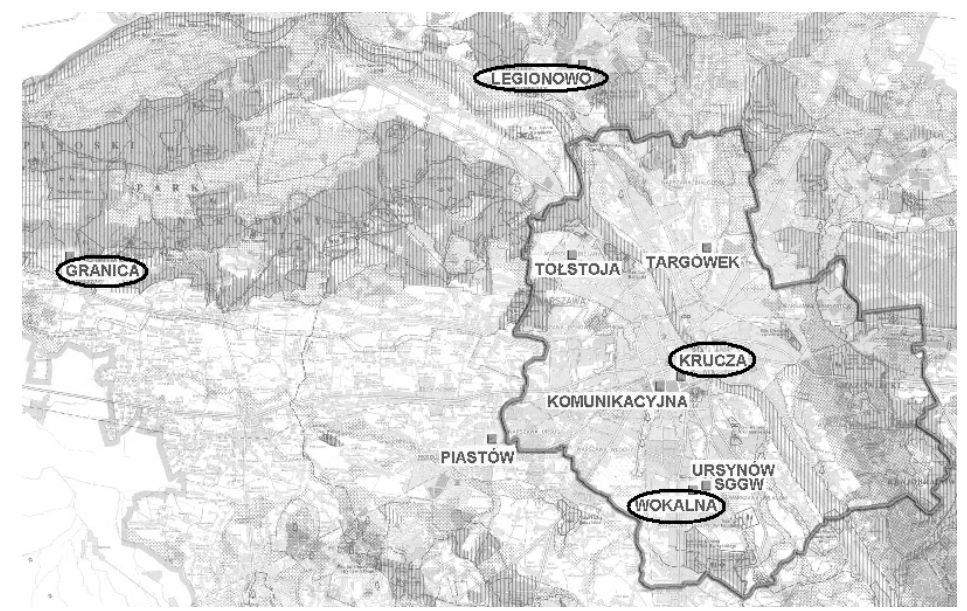

FIGURE 1. Location of the air pollution monitoring stations

Maximum one-hourly recorded value was stated, maximum daily eight-hour mean $120 \mu \mathrm{g} \cdot \mathrm{m}^{-3}$ not to be exceeded on more than 25 days per calendar year, averaged over three years. Eight-hourly $a_{0}+a_{1} \cdot x+a_{2} \cdot x^{2}+a_{3} \cdot x^{3}+a_{4} \cdot x^{4}$

where:

$a_{0} \cdot a_{1} \cdot a_{2} \cdot a_{3} \cdot a_{4}-$ polynomial's coefficients, $x$-dependent values. 
The values of the concentration of air pollutants in a given period are not only a function of various meteorological conditions, but also depend on emission strengths and sources. on their transmission from the source to the receptor point (meteorological and chemical factors), and on the deposition. Step-wise multiple regression was used to analysis the concentration values of ozone $\left(\mathrm{O}_{3}\right)$ as a variable dependent on meteorological elements, such as solar radiation (SR), air temperature (AT), relative air humidity $(\mathrm{RH})$, wind speed (VS) and atmospheric pressure (BP), are independent variables affecting the value of the concentration. For the statistical analysis, which includes development of multiple regression equations between the concentration of ozone and the concentration of nitrogen dioxide and meteorological elements, the study selected episodes of high concentrations of ozone, for example, situations when the value of $\mathrm{O}_{3}$ concentration exceeded the limit value of $120 \mu \mathrm{g} \cdot \mathrm{m}^{-3}$.

\section{RESULTS AND DISCUSSION}

In the years 2008-2012 average values of ozone concentration were comparable in all considered stations and were included in the range from $41.2 \mu \mathrm{g} \cdot \mathrm{m}^{-3}$ for station Krucza to $48.1 \mu \mathrm{g} \cdot \mathrm{m}^{-3}$ for station Granica. In particular years the least average values of ozone concentration were recorded in Krucza $\left(40.4 \mu \mathrm{g} \cdot \mathrm{m}^{-3}\right.$ in 2012) and the greatest ones in Granica $\left(49.8 \mu \mathrm{g} \cdot \mathrm{m}^{-3}\right.$ in 2011) - Figure 2. The greatest monthly average values of ozone concentration occurred on spring and summer months (April to June) and they were included in the range from $63.7 \mu \mathrm{g} \cdot \mathrm{m}^{-3}$ in station Krucza on April to $72.3 \mu \mathrm{g} \cdot \mathrm{m}^{-3}$ in Granica on May. The least values of $\mathrm{O}_{3}$ concentration always occurred in autumn and were included in the range from $15.8 \mu \mathrm{g} \cdot \mathrm{m}^{-3}$ (station Krucza) to $24.6 \mu \mathrm{g} \cdot \mathrm{m}^{-3}$ (station Granica) - Figure 3. Table 1 presents seasonal average concentration of ozone in the period 2008-2012. The values of concentration in summer and spring (warm half-year

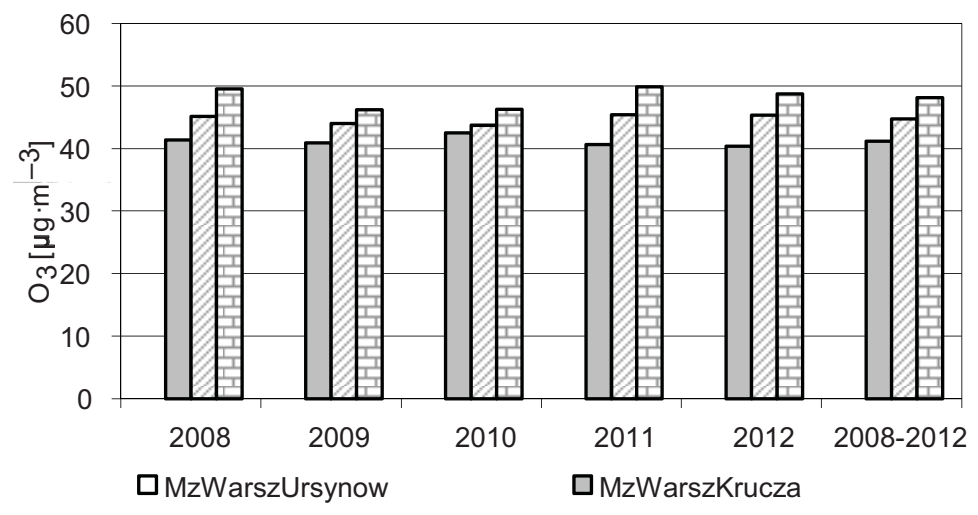

FIGURE 2. Average values ozone concentration $\left[\mu \mathrm{g} \cdot \mathrm{m}^{-3}\right]$ for years 2008-20012 


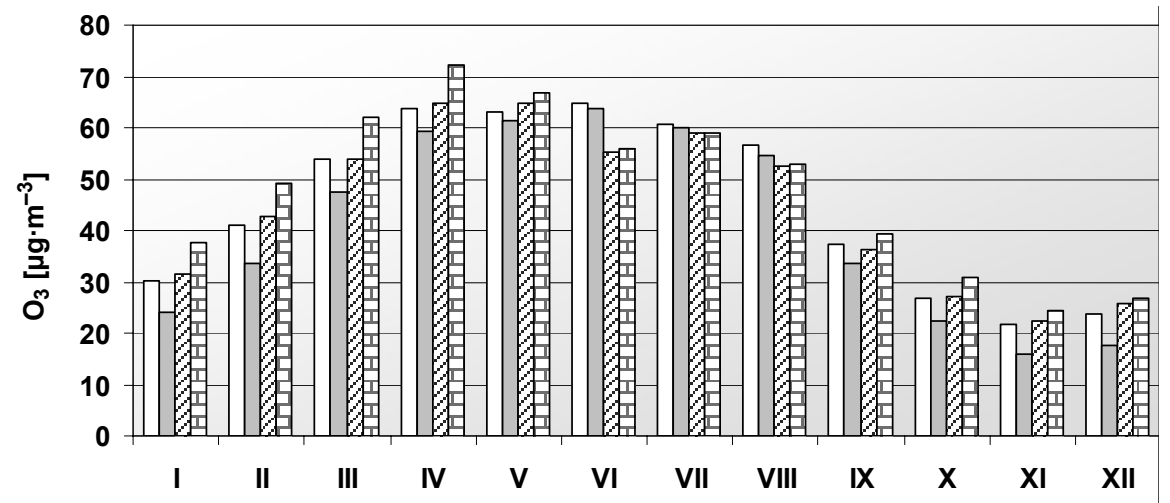

MzWarszUrsynow $\square$ MzWarszKrucza $\square$ MzLegionZegIMGW $\square$ MzGranicaKPN

FIGURE 3. Average values ozone concentration $\left[\mu \mathrm{g} \cdot \mathrm{m}^{-3}\right]$ for months in years 2008-2012

TABLE 1. Average values ozone concentration $\left[\mu \mathrm{g} \cdot \mathrm{m}^{-3}\right]$ for the seasons in 2008-2012

\begin{tabular}{|l||c||c|c|c|}
\hline Station code & Spring (III-V) & $\begin{array}{c}\text { Summer } \\
\text { (VI-VIII) }\end{array}$ & Autumn (IX-XI) & Winter (XII-II) \\
\hline MzWarszUrsynow & 60.3 & 60.7 & 28.6 & 31.7 \\
\hline MzWarszKrucza & 56.1 & 59.4 & 24.0 & 25.2 \\
\hline MzLegionZegIMGW & 61.2 & 55.5 & 28.6 & 33.4 \\
\hline MzGranicaKPN & 67.0 & 56.0 & 31.6 & 37.8 \\
\hline
\end{tabular}

period) were above twice greater than concentration in autumn and winter.

For all considered stations in analyzed period 2008-2012, in particular years the days with target value exceeded excess of maximum daily eight-hour mean $120 \mu \mathrm{g} \cdot \mathrm{m}^{-3}$ not to be exceeded on more than 25 days per calendar year (Ministry Regulation 2012). Maximum eighthourly concentration (were noted, but it was not the excess of frequency limit concentration 25 days per year). Number of days with target value excess varies between 7 days for Krucza and 20 days for Granica, but in particular years between 0 days for Krucza in 2012 and 32 days for Granica in 2008 (Fig. 4). Thereby, excess of alert threshold was not noted $\left(180 \mu \mathrm{g} \cdot \mathrm{m}^{-3}\right)$. Maximum values of one-hourly and eight-hourly ozone concentration were similar for all considered stations and the greatest values were recorded in station Granica - 179.9 and $157.3 \mu \mathrm{g} \cdot \mathrm{m}^{-3}$ respectively, and the least in Legionowo - 169.3 and $147.3 \mu \mathrm{g} \cdot \mathrm{m}^{-3}$ respectively (Fig. 5).

Hourly courses of ozone concentration in particular seasons with partition on work days and weekend days were shown in the Figure 6. Typical course including one maximum about 2 and 4 P.M. and one minimum about 6 and 7 A.M. is noted for all seasons. In spring and summer maximum appears 1 or 2 hours earlier than in autumn and winter, probably because of the longer days in these seasons. The greatest values of ozone concentration and its greatest variation at once 


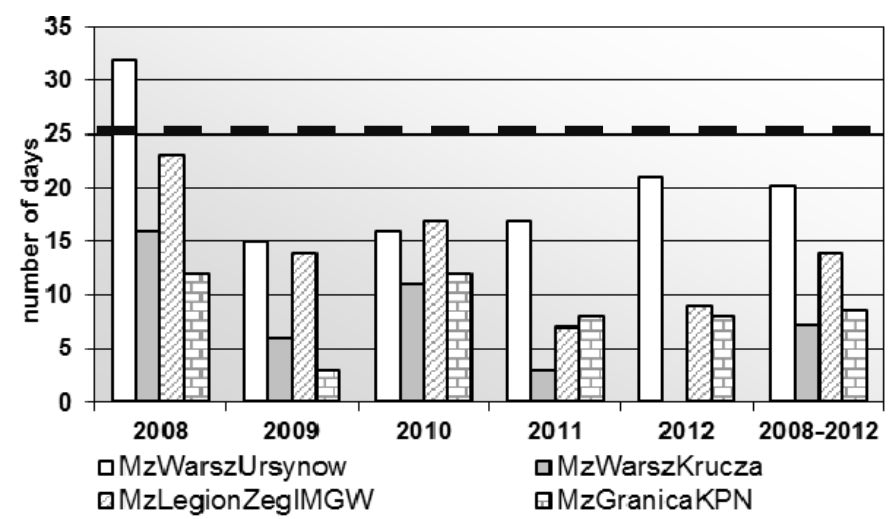

FIGURE 4. Number of days with high level of troposphere ozone concentration $\left(120 \mu \mathrm{g} \cdot \mathrm{m}^{-3}\right)$ occurrence in the period 2008-2012

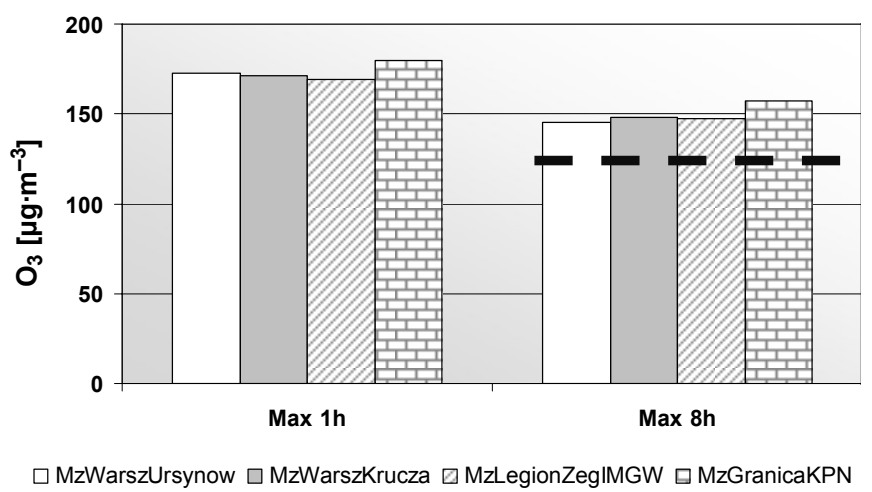

FIGURE 5. Maximum values of 1-h and 8-h ozone concentration $\left[\mu \mathrm{g} \cdot \mathrm{m}^{-3}\right]$ in period 2008-2012

occurs in spring and summer. Unlike this, the least values of ozone concentration and its least variation occurs in autumn and winter. Meteorological conditions in spring and summer months, especially temperature and radiation which lead to ozone formation contribute to this distribution of concentration. Other researches, of influence of meteorological conditions on ozone formation in different regions of Poland give very similar results (Godłowska and Tomaszewska 2002, Nidzgorska-Lencewicz 2011 for Szczecin, and Rozbicka et al. 2010, Rozbicka et al. 2014 for Warsaw). For example in Szczecin (2005-2007) the greatest average concentrations of ozone $\left(69 \mu \mathrm{g} \cdot \mathrm{m}^{-3}\right)$ was stated in spring, the smallest in autumn and winter and in terms of week measurements the imission level in weekend days was dominant over the rest of the week, marking the strongest in the spring. There are not so much researches about the relationship between ozone concentration and meteorological conditions in Poland.

In summer, the differences between the least ozone concentration values are greater and vary between $45 \mu \mathrm{g} \cdot \mathrm{m}^{-3}$ (station Krucza) and $64 \mu \mathrm{g} \cdot \mathrm{m}^{-3}$ (sta- 
tion Granica), in spring between 45 and $55 \mu \mathrm{g} \cdot \mathrm{m}^{-3}$ in all types of days - both work days and weekend days. In winter, the differences are significantly less and vary between $10 \mu \mathrm{g} \cdot \mathrm{m}^{-3}$ (station $\mathrm{Kru}$ cza) and $15 \mu \mathrm{g} \cdot \mathrm{m}^{-3}$ (in station Granica for weekend days and in Ursynów for work days).

Tropospheric ozone concentration during work days in winter is slightly greater than the concentration during weekends, but only in stations situated in the city (Krucza and Ursynów stations). In other stations situated off the city (Granica and Legionowo) the relation is in opposite. Ozone concentration during weekend days is greater than the concentration during work days. In autumn, the variation of ozone concentration is from $24 \mu \mathrm{g} \cdot \mathrm{m}^{-3}$ (station Krucza) to $38 \mu \mathrm{g} \cdot \mathrm{m}^{-3}$ (station Granica) and during the weekend days is greater than during the work days for all considered stations. On the base course of hourly ozone concentration is shown that values of concentration for weekend days are greater than values for work days in case of all stations and in all seasons. This effect occurs in Poland (Hoffman and Jasiński 2000; Nidzgorska-Lencewicz 2011) and worldwide (Atkinson-Palombo et al. 2006; Blanchard and Tanenbaum 2006; Blanchard et al. 2008; Shan et al. 2008; Seguel et al. 2012) and it is called weekend effect (WE). It characterizes greater values of tropospheric ozone concentration during weekend days in comparison to work days despite less emission of the precursors especially oxides of nitrogen from vehicles and industrial sources. Understanding of the weekend effect could ensure more efficient strategy of air pollution control in urban areas.
During summer and spring for station Granica maximum values of ozone concentration on work days is slightly less or almost equal for both types of days. Greater differences between values of $\mathrm{O}_{3}$ concentration for work days and weekend days occurred during autumn and winter with greater values of concentration for weekend days. Similar relation are obtained for Szczecin for the period 2005-2007 (Nidzgorska-Lencewicz 2011). On the other stations were vice versa - the higher maximum ozone concentration occurred in weekend days than the work days for all seasons (Table 2).

Polynomials - best characterizing average daily courses of ozone concentration functions, are presented in Figure 7. Values of correlation coefficient (R) are included in the range from 0.51 to 0.99 and all equations are statistically at $\alpha=$ $=0.01$. The highest values of correlation coefficients were recorded for spring and summer for both types of days.

In Table 3 regression equations of ozone concentration and nitrogen dioxide and meteorological elements are shown. All equations are statistically significant $(\alpha=1 \%)$ and correlation coefficients are very high (above $\mathrm{R}=0.81$ ). Calculated equations include from three to five independent variables. Air temperature, solar radiation, wind velocity and relative humidity and nitrogen dioxide concentration effect on tropospheric ozone concentration.

Figure 8 presents one of episodes of high level of ozone concentration. During year 2012, since 27th April until 1st May one-hourly ozone concentration rised over $120 \mu \mathrm{g} \cdot \mathrm{m}^{-3}$ for all the days of the episode. Durations of high level concentration were $6,8,9$ and 10 hours 

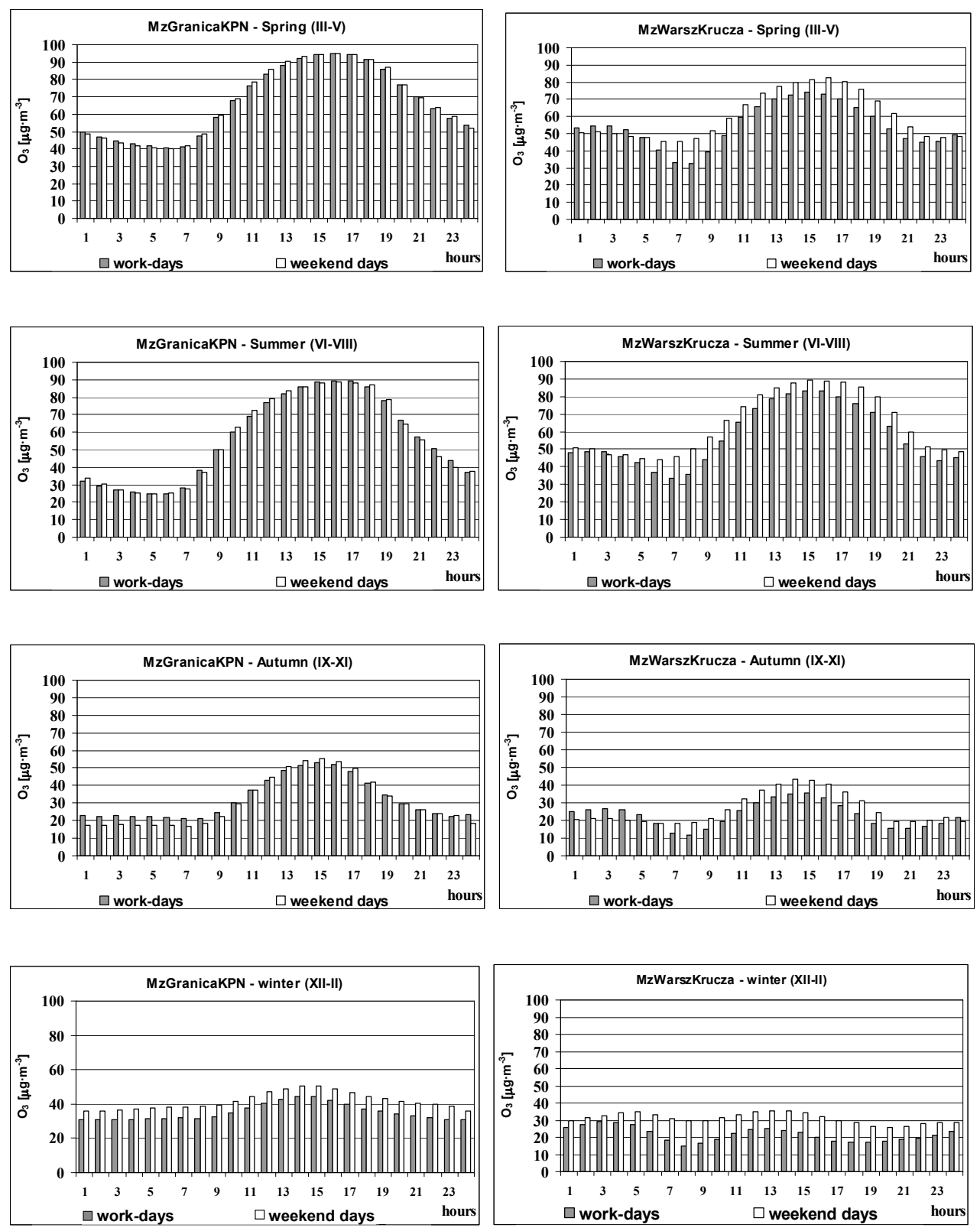

FIGURE 6. Average hourly concentrations of ozone $\left[\mu \mathrm{g} \cdot \mathrm{m}^{-3}\right]$ by seasons in Warsaw Agglomeration in years 2008-2012 

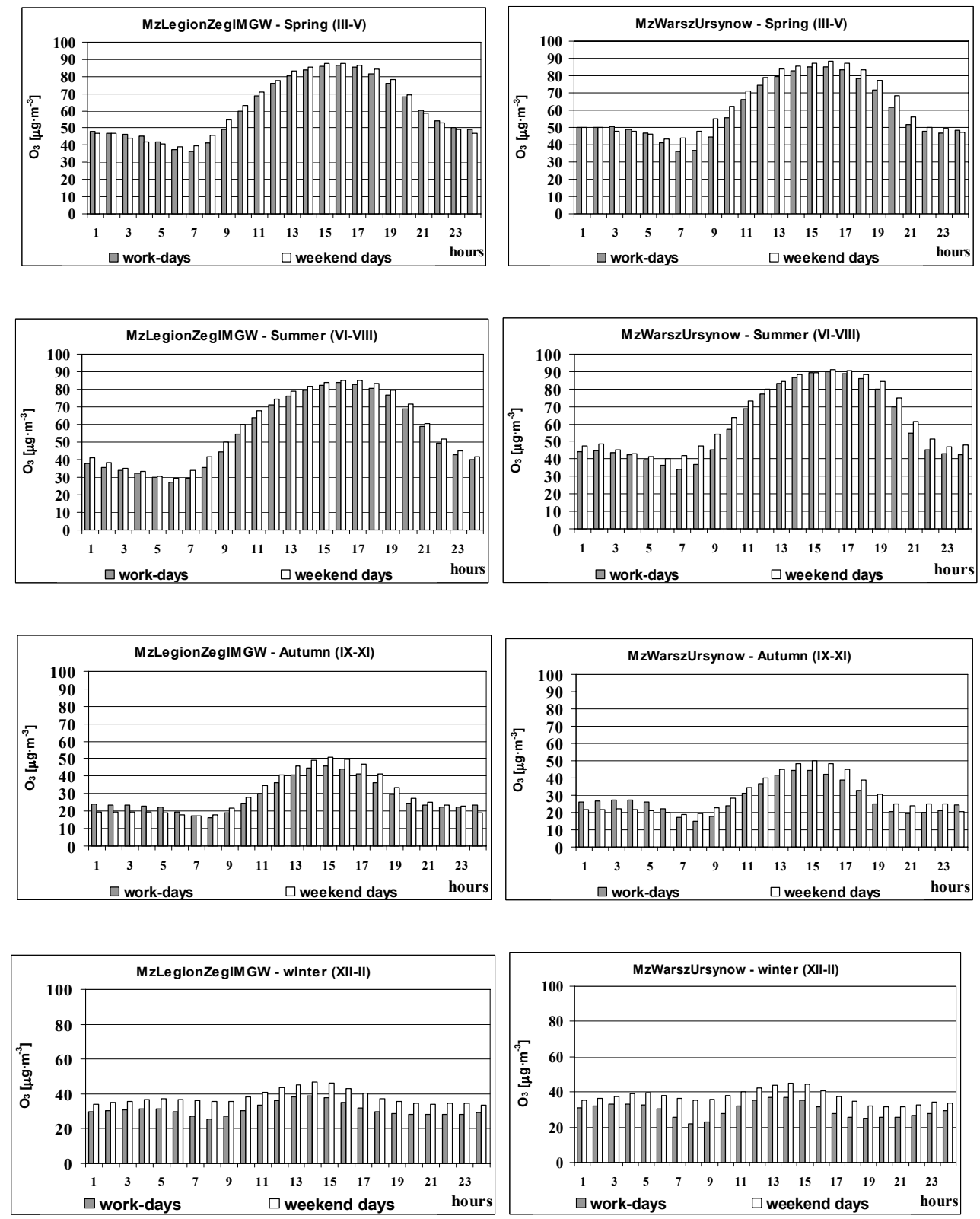

FIGURE 6. cont. 

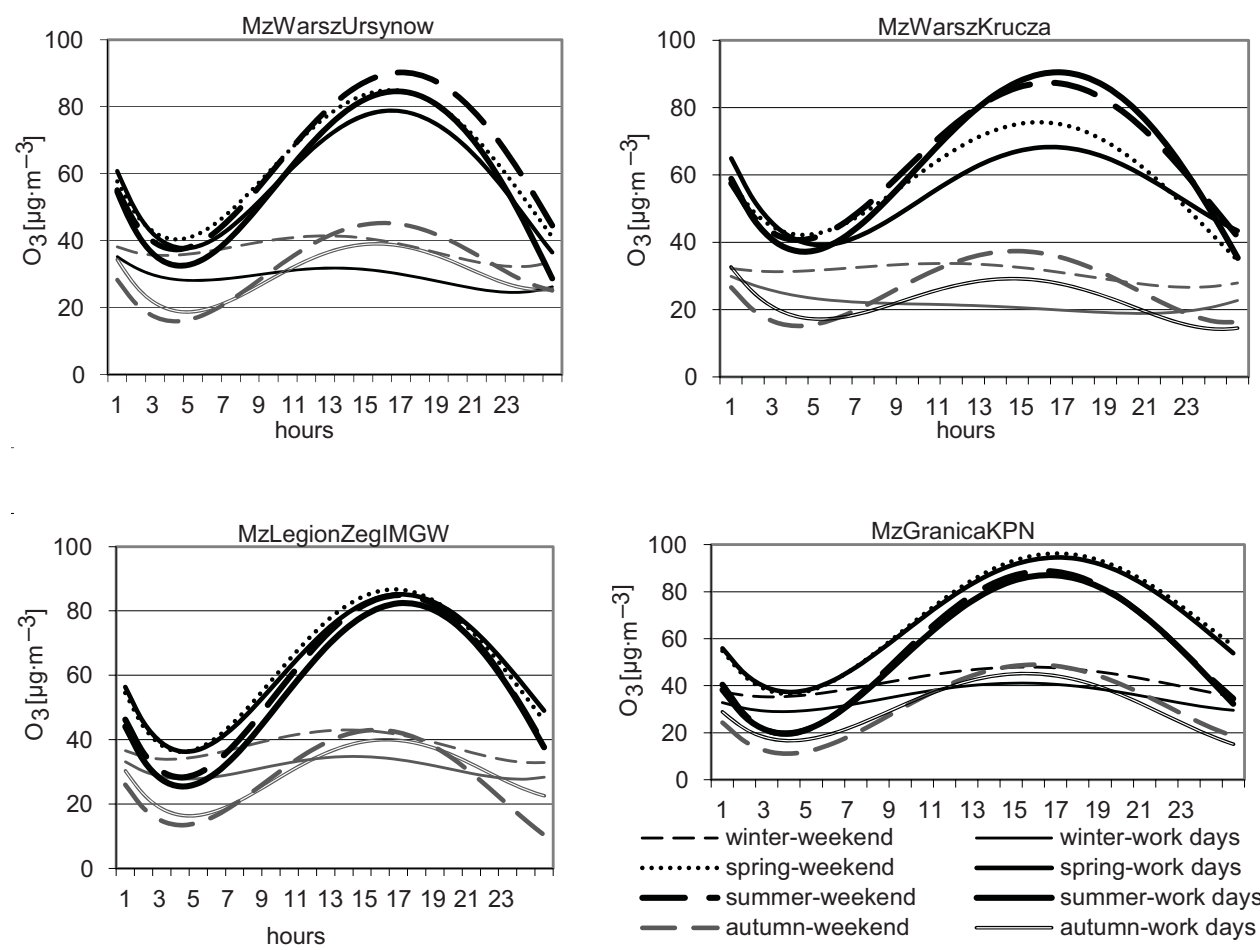

FIGURE 7. Polynomials - hourly courses of ozone concentration in particular seasons in period 2008$-2012$

TABLE 2. Maximum and minimum values on the base of hourly course of ozone concentration $\left[\mu \mathrm{g} \cdot \mathrm{m}^{-3}\right.$ ] in particular seasons in period 2008-2012

\begin{tabular}{|l|l|c|c|c|c|c|c|c|c|}
\hline \multirow{2}{*}{ Station code } & \multirow{2}{*}{ Values } & \multicolumn{2}{|c|}{ Spring } & \multicolumn{2}{c|}{ Summer } & \multicolumn{2}{c|}{ Autumn } & \multicolumn{2}{c|}{ Winter } \\
\cline { 3 - 11 } & & Sa-Su & Mo-Fr & Sa-Su & Mo-Fr & Sa-Su & Mo-Fr & Sa-Su & Mo-Fr \\
\hline \multirow{2}{*}{ MzWarszGranica } & Max & 94.7 & 95.0 & 88.6 & 89.5 & 55.2 & 52.9 & 50.6 & 44.3 \\
\cline { 2 - 11 } & Min & 40.1 & 40.9 & 24.5 & 24.7 & 16.9 & 21.1 & 35.7 & 30.7 \\
\hline \multirow{2}{*}{ MzLegioZegIMGW } & Max & 87.8 & 86.4 & 84.9 & 83.8 & 50.6 & 45.8 & 46.9 & 38.6 \\
\cline { 2 - 11 } & Min & 39.3 & 36.5 & 29.6 & 27.4 & 17.4 & 16.1 & 33.3 & 25.6 \\
\hline \multirow{2}{*}{ MzWarszUrsynów } & Max & 88.5 & 85.2 & 90.8 & 89.8 & 50.0 & 44.7 & 45.0 & 37.0 \\
\cline { 2 - 10 } & Min & 43.5 & 35.9 & 40.0 & 33.8 & 18.9 & 14.7 & 31.3 & 21.8 \\
\hline \multirow{2}{*}{ MzWarszKrucza } & Max & 82.5 & 74.0 & 89.6 & 83.8 & 43.1 & 35.4 & 35.6 & 28.9 \\
\cline { 2 - 10 } & Min & 45.7 & 32.6 & 44.2 & 27.4 & 18.2 & 11.6 & 25.5 & 14.9 \\
\hline \hline
\end{tabular}


TABLE 3. Multiple regression equations between troposphere ozone concentration (above $120 \mu \mathrm{g} \cdot \mathrm{m}^{-3}$ ) and independent variables and basic statistics of the equations for analyzed stations in 2008-2012

\begin{tabular}{|l|l|c|c|c|c|c|}
\hline Station code & Regression equations & $\mathrm{R}$ & $\mathrm{R}^{2}$ & $\mathrm{SEE}$ & $\mathrm{F}$ & $\mathrm{n}$ \\
\hline MzWarszUrsynow & $\begin{array}{l}\mathrm{O}_{3}=118.99+1.278 \cdot \mathrm{AT}+7.958 \cdot \mathrm{VS}- \\
-1.069 \cdot \mathrm{RH}-0.013 \cdot \mathrm{SR}-0.589 \cdot \mathrm{NO}_{2}\end{array}$ & 0.88 & 78 & 19.2 & 832 & 1175 \\
\hline MzWarszKrucza & $\begin{array}{l}\mathrm{O}_{3}=55.972+2.355 \cdot \mathrm{AR}+0.039 \cdot \mathrm{SR}- \\
-0.88 \cdot \mathrm{NO}_{2}\end{array}$ & 0.81 & 65 & 24.8 & 315 & 505 \\
\hline MzLegionZegIMGW & $\begin{array}{l}\mathrm{O}_{3}=1005.8+0.569 \cdot \mathrm{AR}-1.213 \cdot \mathrm{RH}- \\
-0.854 \cdot \mathrm{BP}-0.015 \cdot \mathrm{SR}-0.982 \cdot \mathrm{NO}\end{array}$ & 0.87 & 76 & 19.9 & 600 & 972 \\
\hline MzGranicaKPN2008 & $\begin{array}{l}\mathrm{O}_{3}=186.645+11.023 \cdot \mathrm{SR}-1.59 \cdot \mathrm{RH}- \\
-0.04 \cdot \mathrm{SR}-0.59 \cdot \mathrm{NO}_{2}\end{array}$ & 0.93 & 87 & 15.9 & 1174 & 727 \\
\hline MzGranicaKPN2009 & $\begin{array}{l}\mathrm{O}_{3}=132.543+1.85 \cdot \mathrm{AR}-5.14 \cdot \mathrm{VS}- \\
-0.83 \cdot \mathrm{RH}-1.69 \cdot \mathrm{NO}_{2}\end{array}$ & 0.91 & 83 & 16.2 & 399 & 330 \\
\hline MzGranicaKPN2010 & $\begin{array}{l}\mathrm{O}_{3}=153.024+1.207 \cdot \mathrm{AR}+10.74 \cdot \mathrm{VS}- \\
-1.42 \cdot \mathrm{RH}-0.028 \cdot \mathrm{SR}-0.97 \cdot \mathrm{NO} 2\end{array}$ & 0.93 & 86 & 18.3 & 466 & 370 \\
\hline MzGranicaKPN2011 & $\begin{array}{l}\mathrm{O}_{3}=199.728-1.396 \cdot \mathrm{RH}-0.096 \cdot \mathrm{SR}- \\
-1.93 \cdot \mathrm{NO}_{2}\end{array}$ & 0.82 & 67 & 20.1 & 271 & 397 \\
\hline MzGranicaKPN2012 & $\begin{array}{l}\mathrm{O}_{3}=128.114+1.81 \cdot \mathrm{AR}-1.30 \cdot \mathrm{RH}- \\
-1.026 \cdot \mathrm{NO}_{2}\end{array}$ & 0.95 & 90 & 13.8 & 1495 & 487 \\
\hline
\end{tabular}

Explanations: $\mathrm{O}_{3}$ - troposphere ozone concentration in $\mu \mathrm{g} \cdot \mathrm{m}^{-3}$, AT - air temperature in ${ }^{\circ} \mathrm{C}, \mathrm{VS}-$ wind speed in $\mathrm{m} \cdot \mathrm{s}^{-1}, \mathrm{RH}$ - relative humidity in $\%, \mathrm{SR}$ - total solar radiation in $\mathrm{W} \cdot \mathrm{m}^{-2}, \mathrm{BP}$ - barometric pressure in $\mathrm{hPa}, \mathrm{NO}_{2}$ - nitrogen dioxide concentration in $\mu \mathrm{g} \cdot \mathrm{m}^{-3}, \mathrm{R}$ - correlation coefficient, $\mathrm{R}^{2}$ - squared correlation coefficient in \%, SEE - standard error of estimation in $\mu \mathrm{g} \cdot \mathrm{m}^{-3}, \mathrm{~F}-$ Fisher-Snedecor F-test empirical value, $\mathrm{n}$ - number of cases (hours).

respectively on successive days. Maximumvalue $\left(154.4 \mu \mathrm{g} \cdot \mathrm{m}^{-3}\right)$ occuredon 30 th April. In spite of spring season high value of maximum air temperature $\left(30.2^{\circ} \mathrm{C}\right)$ and high value of total solar radiation $\left(1,300 \mathrm{~W} \cdot \mathrm{m}^{-2}\right)$ were recorded. Wind velocity was less than $4 \mathrm{~m} \cdot \mathrm{s}^{-1}$ and relative humidity was less than $50 \%$ during all the days. Wind direction varied (with $\mathrm{W}, \mathrm{S}$ and $\mathrm{E}$ most frequent directions). Concentration of $\mathrm{NO}_{2}$ was extremely low (maximum value $20 \mu \mathrm{g} \cdot \mathrm{m}^{-3}$ was recorded). On the base of courses of mentioned elements it is state meteorological conditions played were significant role in formation of high ozone concentration persisting even 10 hours a day.

\section{CONCLUSIONS}

On the base of obtained results for the period 2008-2012 in analyzed stations it can be stated:

1. Average values of ozone concentration are greater for the station Granica situated out of Agglomeration area and represents the rural site in comparison of values for the stations Krucza and Ursynów situated inside the city and represents the urban site. The greatest values of ozone concentration is $49.8 \mu \mathrm{g} \cdot \mathrm{m}^{-3}$ (for station Granica in 2011), the least value is $40.4 \mu \mathrm{g} \cdot \mathrm{m}^{-3}$ (for station Krucza in 2012). The greatest average annual 

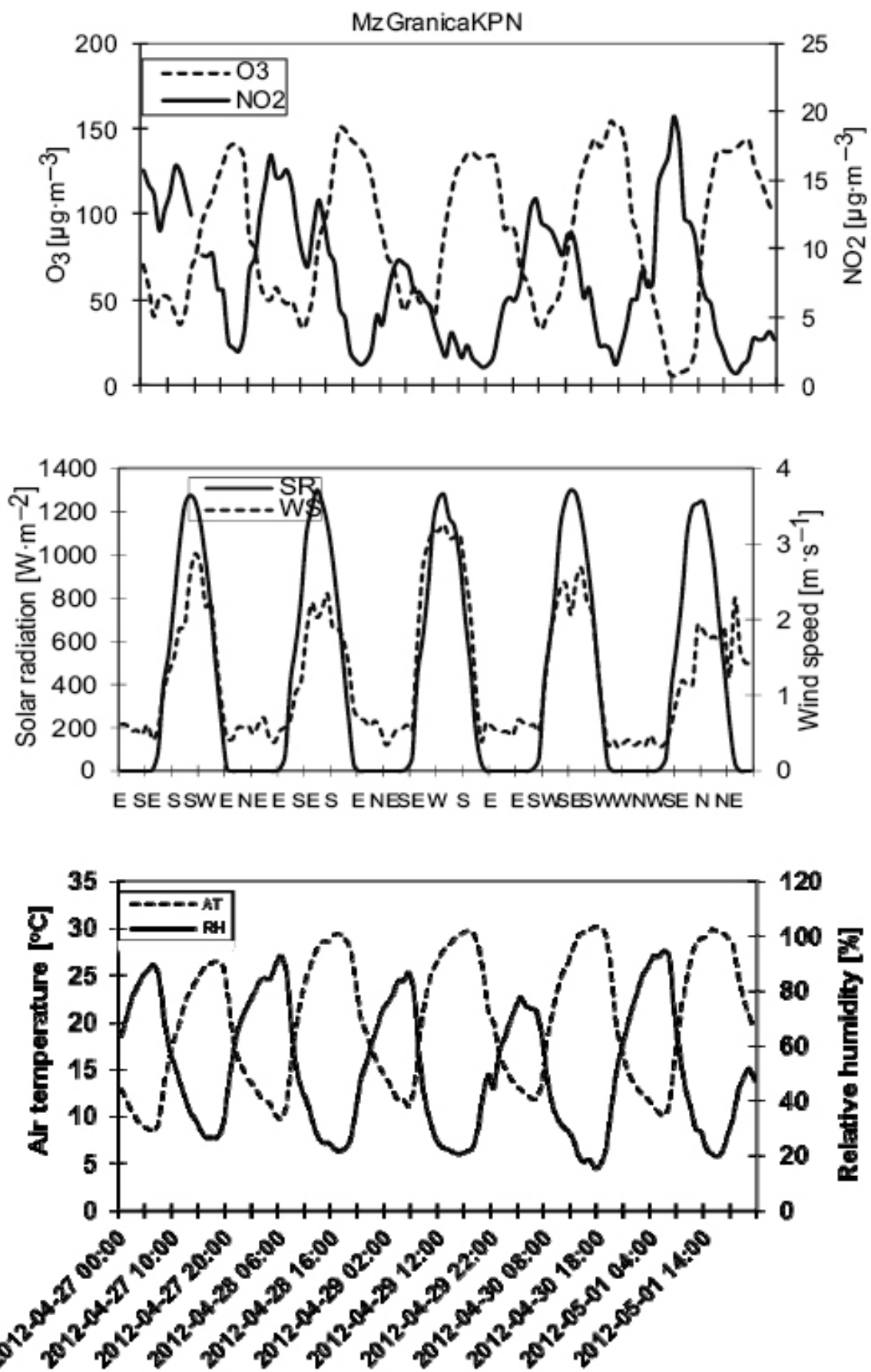

FIGURE 8. Course of ozone and nitrogen dioxide concentrations and meteorological elements during five days episode of high level ozone concentration in 2012 on days 27th April to 1st May in station Granica 
value for all period 2008-2012 was noted in station Granica $\left(48.1 \mu \mathrm{g} \cdot \mathrm{m}^{-3}\right)$ and the least in station Krucza $\left(41.2 \mu \mathrm{g} \cdot \mathrm{m}^{-3}\right)$.

2. Values of tropospheric ozone concentration recorded during summer and spring were above twice greater than the concentration recorded during autumn and winter.

3 . Courses of hourly ozone concentrations are similar for all considered stations and all seasons. There is one maximum about 2 and 4 P.M. and one minimum about 6 and 7 A.M. The greatest values are recorded out of the agglomeration for the station Granica in spring $\left(95 \mu \mathrm{g} \cdot \mathrm{m}^{-3}\right)$ and the least ones for the station Krucza in winter $\left(10 \mu \mathrm{g} \cdot \mathrm{m}^{-3}\right)$.

4. Diurnal course of ozone concentration in weekend days characterizes greater values than in work days, but the differences are little. The greatest differences between weekend days concentration and work days concentration occur during autumn and winter, but in the same time the differences during the day are the least, especially in urban site stations.

5. For all considered stations in analyzed period 2008-2012, in particular years the days with $120 \mu \mathrm{g} \cdot \mathrm{m}^{-3}$, not to be exceeded more than 25 days per calendar year excess of maximum eight-hourly average concentration were noted, but it was not the excess of frequency limit concentration (25 days per year).

6. The results of regression equations expressing the various measures as a function of human activity, meteorological conditions show statistically significant relationships not only in the measures of the hourly, seasonal courses, but also in the goodness of fit of polynomial function that describe the hourly cycle in ozone. The obtained regression equations may be useful in predicting the occurrence of high troposphere ozone concentrations in the Warsaw Agglomeration.

\section{REFERENCES}

ATKINSON-PALOMBO C.M., MILLER J.A., BALLING Jr. R.C. 2006: Quantifying the ozone ,weekend effect" at various locations in Phoenix. Arizona. Atmospheric Environment 40, 7644-7658.

BLANCHARD C.L., TANENBAUM S. 2006: Weekday/weekend differences in ambient air pollutant concentrations in Atlanta and the southeastern United States. Journal of the Air \& Waste Management Association 56, 271-284.

BLANCHARD C.L., TANENBAUM S., LAWSON D.R. 2008: Differences between weekday and weekend air pollutant levels in Atlanta; Baltimore; Chicago; Dallas-Fort Worth; Denver; Houston; New York; Phoenix; Washington. DC; and surrounding areas. Journal of the Air \& Waste Management Association 58, 1598-1615.

BLOOMER B.J., VINNKOW K.Y., DICKERSON R.R. 2010: Changes in seasonal and diurnal cycles of ozone and temperature in the eastern U.S. Atmospheric Environment 44, 2543-2551.

DUAN J., TAN J., YANG L., WU S., HAO J. 2008: Concentration. sources and ozone formation potential of volatile organic compounds (VOCs) during ozone episode in Beijing. Atmospheric Research $88,25-35$.

FUJITA E.M., CAMPBELL D.E., ZIELIŃSKA B., SAGEBIEL J.C., BOWEN J.L., GOLIFF W.S., STOCKWELL W.R., LAWSON D.R. 2003a: Diurnal and weekday variations in the source con- 
tributions of ozone precursors in California's South Coast Air Basin. 1981-2000. Journal of the Air \& Waste Management Association 53, 844-863.

FUJITA E.M., STOCKWELL W.R., CAMPBELL D.E., KEISLER R.E., LAWSON D.R. 2003b: Evolution of the magnitude and spatial extent of weekend ozone effect in California's South Coast Air Basin, 1981-2000. Journal of the Air \& Waste Management Association 53, 802-815.

GENG F., TIE X., XU J., ZHOU G., PENG L., GAO W., TANG X., ZHAO C. 2008: Characterizations of ozone, $\mathrm{NO}_{\mathrm{x}}$, and VOC measured in Shanghai, China. Atmospheric Environment 42, 6873-6883.

GODŁOWSKA J., TOMASZEWSKA A.M. 2002: Meteorologiczne uwarunkowania występowania maksymalnych stężeń ozonu na terenie Polski. Wiadomości IMGW XXV(XLVI), 3.

HEUSS J.M., KAHLBAUM D.F., WOLFF G.T. 2003: Weekday/weekend ozone differences: what can we learn from them? Journal of the Air \& Waste Management Association 53, 772-788.

HOFFMAN S., JASIŃSKI R. 2000: Zmiany stężenia ozonu przy powierzchni ziemi $\mathrm{w}$ przebiegu tygodniowym $\mathrm{w}$ miejscowościach Polski południowej. Cz. II: Kraków. Chem. Inż. Ekolog. 7(4), 385-391.

LAWSON D.R. 2003: Forum - the weekend ozone effect - weekly ambient emissions control experiment. Environmental Management July, 17-25.

MAJEWSKI M., ĆWIEK K. 2013: Effect of a different degree of anthropogenic transformation on the formation of bioclimatic conditions - Warsaw case study. Annals of Warsaw University of Life Sciences - SGGW. Land Reclamation 45 (1), 97-109.

MARR L.C., HARLEY R.A. 2002: Spectral analysis of weekday weekend differences in ambient ozone, nitrogen dioxide, and non-methane hydrocarbon time series in California. Atmospheric Environment 36, 2327-2335.
NIDZGORSKA-LENCEWICZ J. 2011: Czasowy rozkład stężeń ozonu niskotroposferycznego w Szczecinie w latach 2005-2007. Acta Sci.Pol. Formatio Circumiectus 10(1), 47-55.

ROZBICKA K., ROZBICKI T., KLENIEWSKA M. 2010: Preliminary results of research on variability of tropospheric ozone in the southern part of the Warsaw Agglomeration. Acta Agrophysica 179. Rozprawy i Monografie 2, 71-80.

ROZBICKA K., MAJEWSKI G., ROZBICKI T. 2014: Seasonal variation of air pollution in Warsaw conurbation'. Meteorologische Zeitschrift. PrePub DOI 10.1127/0941-2948/2014/0453.

Ministry Regulation 2012: Rozporządzenie Ministra Srodowiska z dnia 24 sierpnia 2012 r. w sprawie poziomów niektórych substancji w powietrzu. Dz.U. 2012 r., poz. 1031.

SEGUEL R.J., MORALES S.R.G.E., LEIVA G.M.A. 2012: Ozone weekend effect in Santiago, Chile. Environmental Pollution 162, 72-79.

SHAN W., YIN Y., ZHANG J., DING Y. 2008: Observational study of surface ozone at an urban site in East China. Research 89, 252-261.

YARWOOD G., STOECKENIUS T.E., HEIKEN J.G., DUNKER A.M. 2003: Modelling weekday/weekend ozone differences in the Los Angeles region for 1997. Journal of the Air \& Waste Management Association 53, 864-875.

Streszczenie: Czasoprzestrzenne zmiany stężenia ozonu w Aglomeracji Warszawskiej (Polska). W opracowaniu wykorzystano cogodzinne wyniki pomiarowe pochodzące $\mathrm{z}$ czterech automatycznych stacji imisji ozonu troposferycznego nadzorowanych przez Wojewódzki Inspektorat Ochrony Środowiska (WIOŚ) w Warszawie w latach 2008-2012. Stacje te reprezentują różne typy obszarów w aglomeracji warszawskiej i w bliskim jej sąsiedztwie. Stwierdzono, że średnie roczne wartości stężenia ozonu są wyższe na stacji Granica położonej poza granicami miasta i reprezentującej rolniczy charakter obszaru niż 
na stacjach położonych w mieście (ul. Krucza, Ursynów) reprezentujących tło miejskie. Wartości stężenia ozonu latem i wiosną były ponaddwukrotnie wyższe niż jesienią i zima. Dzienny przebieg stężenia ozonu dla dni weekendowych charakteryzuje się wyższymi wartościami stężenia niż dla dni roboczych, ale różnice stężenia są niewielkie. Największe różnice stężenia ozonu pomiędzy dniami weekendowymi a dniami roboczymi występują jesienią i zimą przy zarazem najmniejszym zróżnicowaniu stężenia ozonu w ciągu doby, zwłaszcza na stacjach miejskich. Na podstawie uzyskanych wyników zauważa się występowanie podwyższonych wartości stężenia ozonu w dni weekendowe w odniesieniu do dni roboczych. Analiza statystyczna wykazała silny związek między stężeniem ozonu a stężeniem $\mathrm{NO}_{2}$ i elementami meteorologicznymi, zwłaszcza w dni, w których występowało podwyższone stężenie ozonu powyżej $120 \mu \mathrm{g} \cdot \mathrm{m}^{-3}$. Najlepiej dopasowaną funkcją przebiegu jednogodzinnych wartości ozonu w poszczególnych porach roku $\mathrm{z}$ podziałem na dni weekendowe i robocze jest wielomian 4 . stopnia istotny statystycznie.
Stowa kluczowe: ozon, czasowe zmiany, wielomiany, aglomeracja miejska

MS. received August 2013

Authors' addresses:

Katarzyna Rozbicka

Laboratorium - Centrum Wodne

Wydział Budownictwa i Inżynierii Środowiska SGGW

ul. Ciszewskiego 6

02-776 Warszawa, Poland

e-mail: katarzyna_rozbicka@sggw.pl

Tomasz Rozbicki

Wydział Budownictwa i Inżynierii Środowiska SGGW

Katedra Inżynierii Wodnej, Zakład Meteorologii

i Klimatologii

ul. Nowoursynowska 159

02-776 Warszawa, Poland

e-mail: tomasz_rozbicki@sggw.pl 